MYTHAND POETICS

A series edited by GREGORY NAGY

Poetry and Prophecy: The Beginnings of a Literary Tradition edited by James L. Kugel

Also in the series

The Language of Heroes: Speech and Performance in the Iliad by Richard P. Martin

Greek Mythology and Poetics

by Gregory Nagy

Homer and the Sacred City by Stephen Scully 



\section{POETRY AND \\ PROPHECY}

The Beginnings of a Literary Tradition

EDITED BY

James L. KugeL

CORNELL UNIVERSITY PRESS

I T H A C A A N D L O N D N 
Copyright (C) I990 by Cornell University

All rights reserved. Except for brief quotations in a review, this book, or parts thereof, must not be reproduced in any form without permission in writing from the publisher. For information, address Cornell University Press, I 24 Roberts Place, Ithaca, New York I 4850.

First published I990 by Cornell University Press.

International Standard Book Number 0-80 I 4-23 I 0-4 (cloth)

International Standard Book Number 0-8014-9568-7 (paper)

Library of Congress Catalog Card Number 90-2 I 54

Printed in the United States of America

Librarians: Library of Congress cataloging information appears on the last page of the book.

(6) The paper in this book meets the minimum requirements of the American National Standard for Information SciencesPermanence of Paper for Printed Library Materials, ANSI Z39.48-I984. 
Dedicated to the memory of two great scholars, Morton Bloomfield and Dan Pagis 
